\title{
Effect of Smoking on Advanced Stage Cervical Cancer Patient Survival
}

\author{
Pengarub Merokok pada Kesintasan Pasien Kanker Serviks Stadium Lanjut \\ Bram Pradipta ${ }^{1}$, Andrijono ${ }^{2}$, Ahmad Fuady ${ }^{3}$ \\ ${ }^{1}$ Department of Obstetrics and Gynecology \\ ${ }^{2}$ Oncology Gynecology Division Department of Obstetrics and Gynecology \\ ${ }^{3}$ Department of Community Medicine \\ Faculty of Medicine University of Indonesia \\ Jakarta
}

\begin{abstract}
Objective: The researchers aim to investigate the relationship between smoking habit and other factors as prognostic factors of cervical cancer.

Method: We performed a retrospective and prospective cohort study with subjects that are stage IIB-IVB cervical cancer patients in Dr. Cipto Mangunkusumo Hospital followed up from August 2009 to April 2014. The subjects'medical records were reviewed, and patients were interviewed about their current condition by telephone. Questions asked include smoking habit, spouse's smoking habit, and mortality status. Patients that could not be contacted by phone were excluded from the study. Statistical analysis was done using Stata 10.

Result: Out of 390 cervical cancer patients stage IIB-IVB in 2009, there were 270 patients $(69.2 \%)$ that were included in the inclusion criteria. Most of the patients are $40-59$ years old $(82.2 \%)$ and are nonsmokers $(91.8 \%)$. The most frequent clinicopathological characteristic is IIIB $(63.3 \%)$ and squamous cell carcinoma $(71.9 \%)$. The 5year survival rate is $22.6 \%$. There is no statistical significance between advanced stage cervical cancer survival with the patients' or patients' husbands' smoking habit.
\end{abstract}

Conclusion: In our study, smoking habits do not aggravate survival rate of advanced stage cervical cancer patients but further research must be done with more sample. Stage, and tumor size both by physical examination and ultrasound can be used as the prognostic factor.

[Indones J Obstet Gynecol 2015; 3: 170-176]

Keywords: Brigmann Index, cervical cancer, smoking, survival

\begin{abstract}
Abstrak
Tujuan: Mengetahui pengarub merokok terhadap faktor prognosis kanker serviks serta faktor-faktor lain yang berhubungan sehingga dapat membantu memberikan gambaran mengenai prognosis kanker serviks.

Metode: Penelitian ini adalah kohort retrospektif. Sampel penelitian adalah pasien kanker serviks stadium IIB-IVB di RS Dr. Cipto Mangunkusumo mulai dari Agustus 2009 sampai April 2014. Kondisi terakhir pasien di follow up menggunakan telepon. Kondisi yang dinilai adalah pasien masib bidup atan tidak, pasien merokok atan tidak, dan suami pasien merokok atau tidak. Pasien yang tidak dapat dibubungi akan dieksklusi dari penelitian. Analisa data menggunakan Stata 10.

Hasil: Dari 390 pasien kanker serviks stadium IIB-IVB, hanya 270 pasien $(69,2 \%)$ yang memenubi criteria inklusi dan eksklusi. Sebagian besar pasien berusia 40-59 tabun (82,2\%), tidak merokok (91,8\%), suami merokok $(73,3 \%)$. Karakteristik kliniko patologis yang terbanyak adalah stadium IIIB (63,3\%), jenis karsinoma skuamosa (71,9\%). Kesintasan 5 tabun pasien kanker serviks adalab 22,6\%. Hubungan antara kebiasaan merokok pasien dan suami dibandingkan dengan kesintasan pasien kanker serviks menunjukkan hasil yang tidak signifikan.
\end{abstract}

Kesimpulan: Dalam penelitian kami, kebiasaan merokok tidak memperburuk tingkat kelangsungan bidup penderita kanker serviks stadium lanjut, tetapi penelitian lebib lanjut harus dilakukan dengan jumlab sampel lebib besar. Stadium, dan ukuran tumor baik dengan pemeriksaan fisik dan USG dapat digunakan sebagai faktor prognostik.

[Maj Obstet Ginekol Indones 2015; 3: 170-176]

Kata kunci: kanker serviks, merokok, Indeks Brigmann, kesintasan

Correspondence: Bram Pradipta. Department of Obstetrics and Gynecology, Faculty of Medicine University of Indonesia. Jakarta.

Telephone: 0819-08065674, Email: bram_p@yahoo.com

\section{INTRODUCTION}

The mortality and morbidity rate of cervical cancer globally is 275.000 and 529.000 , respectively, making it the third leading cancer globally and the first leading cancer in developing country. ${ }^{1-4}$ Smoking has been a well-known risk factor for cervical cancer. According to the WHO in 2008, Indonesia is the third leading country in number of smoker globally, with 59.8 million smokers (approximately 225 billion cigarettes per year), and $2.7 \%$ of them are women. It is estimated that each year there are 2,3 million Indonesian women who are active smokers while another 1.6 million women are non-cigarette tobacco users. Tobacco contains carcinogenic material; burned tobacco produces polycyclic aromatic hydrocarbon heterocyclic nitrosamines, which gives negative effects to people who consume it.

The role of smoking habit as prognostic factor for cervical cancer patients in Dr. Cipto Mangunkusumo Hospital has not been established yet. The 
most well known prognostic factor for cervical cancer patient is its stage. Other prognostic factors contributing to cervical cancer patient outcome is important to be investigated. Therefore, the study aims to investigate the relationship between smoking and other factors as prognostic factors of cervical cancer.

\section{METHODS}

The study uses cohort retrospective method. Subjects are patients from Dr. Cipto Mangunkusumo Hospital with advanced stage (Stage IIB-IVB) cervical cancer from August 2009 - April 2014. Demographic and clinicopathological characteristics were obtained from medical record. Patients were contacted via telephone, from numbers listed on the medical record, and asked their mortality status, smoking habit and husband's smoking habit. Exclusion criteria include patients who could not be contacted by telephone. Patients' survival rate was calculated by finding the interval (in days) between date of death and date of diagnosis. Outcome measure is survival rate, which is determined by months after diagnosis. The follow up period is 58 months, therefore survival until the end of the follow up period is considered as 5-year survival rate. Statistical analysis was done using Stata 10.

\section{RESULTS}

Among 390 patients with cervical cancer stage IIBIVB in RSCM since August 2009, 270 (69.2\%) patients were successfully interviewed by phone. Sixty five percent of these patients were referred by rural hospital, $28.1 \%$ patients were referred by gynecologist and rest of them were referred by primary health care centers. Occupation of the subjects was mostly $(85.2 \%)$ housewives. Patients were divided into ages above 60 years old $(10.4 \%)$, between $40-59$ years old $(82.2 \%)$ and below 40 years of age $(7.4 \%)$. While, the age of cervical cancer onset were found mostly in the $40-59$ age group with $65 \%$ belonging to this group. Most of the patients (41.1\%) has an undergraduate degree, and $64.1 \%$ had 3 children or more. $89.3 \%$ of the patients never had a pap smear examination before.

The physical examination showed that most of the subjects $(80 \%)$ had tumors sized 4-8 centimeters, and rest $(15.2 \%)$ had tumors less than $4 \mathrm{~cm}$. On ultrasonography findings, only $66.7 \%$ of the patients had 4-8 centimeters tumor. Patients were also classified into The International Federation of Gynecology and Obstetrics (FIGO) stages, results were as follows: IIB: $22.2 \%$, IIIA: $4.8 \%$, IIIB: $63.3 \%$; and IVA: $9.6 \%$. $85 \%$ patients didn't have any pelvic lymph node enlargement. From histopathology findings, most patients $(71.9 \%)$ were found to have squamous cell carcinoma (SCC) histological subtype; with $66.6 \%$ of them being moderately differentiated and $16.7 \%$ being well differentiated. $81.3 \%$ of the subjects' tumor cells were not keratinized, and no lymphovascular invasion was found in $86.7 \%$ of patients. Therapy modalities were mostly radiotherapy $(42.2 \%)$ and chemoradiation with cisplatin-ifosfamide $(30 \%)$.

The patients were then divided into the light, moderate and heavy smoker based on the Brigmann's Index. Only $8.2 \%(n=8)$ of patients admitted to be a smoker while the rest claim to not smoke; $73.3 \%$ of the subjects' spouses were smokers.

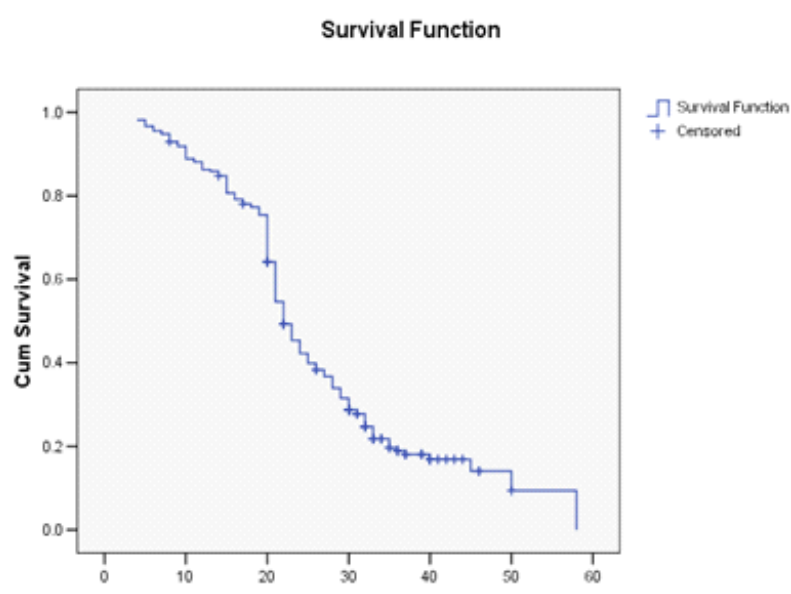

Figure 1. Advance Stage Cervical Cancer 5-years Survival Rate.

The average survival rate amongst patients was 22 months $(\mathrm{SD}=4-58)$. While those who made it until the end of the follow up period (5-year survival rate) of advanced stage cervical cancer patients was $22.6 \%$. The study showed that survival in the first year was $86.3 \%$, decreasing to half in the second year to $43.3 \%$, and kept decreasing to $24.4 \%, 23.3 \%$, and $22.6 \%$ for the third, fourth, and fifth year, respectively.

Bivariate analysis showed no statistically significant relationship between the size of the tumor, lymphadenopathy, cell differentiation, lymphovascular invasion, keratinization stage of cervical cancer, and response to therapy with smoking status of both the patient and the husband. 
Table 1. Bivariate Analysis of the Relationship between Prognostic Factor and Survival

\begin{tabular}{lccccc}
\hline \hline & & & & \multicolumn{2}{c}{$95 \%$ CI } \\
\cline { 5 - 6 } & & p & HR & Lower limit & Upper limit \\
\hline Age & -0.161 & 0.317 & 0.852 & 0.622 & 1.167 \\
Parity & -0.059 & 0.599 & 0.942 & 0.755 & 1.176 \\
Pap Smear & 0.144 & 0.504 & 1.155 & 0.757 & 1.762 \\
Tumor size & 0.247 & 0.104 & 1.281 & 0.950 & 1.726 \\
Tumor size USG & 0.561 & $<0.001$ & 1.752 & 1.354 & 2.267 \\
Cancer stage & 1.518 & $<0.001$ & 4.564 & 3.527 & 5.906 \\
Pelvic lymph node & -0.148 & 0.458 & 0.863 & 0.584 & 1.274 \\
Histopathology & 0.054 & 0.486 & 1.056 & 0.906 & 1.229 \\
Cell differentiation & 0.152 & 0.008 & 1.164 & 1.041 & 1.302 \\
Lymphovascular invasion & 0.251 & 0.220 & 1.285 & 0.860 & 1.919 \\
Brigmann Index & -0.029 & 0.874 & 0.972 & 0.679 & 1.389 \\
Brigmann Index Patient Husband & 0.072 & 0.282 & 1.075 & 0.942 & 1.227 \\
Keratinization & 0.192 & 0.236 & 1.212 & 0.882 & 1.666 \\
Therapy response & 0.261 & 0.066 & 1.299 & .982 & 1.717 \\
\hline \hline
\end{tabular}

Table 1 shows that there is a significant relationship between cervical cancer survival rate with the prognostic factors: tumor size, cell differentiation, lymphovascular invasion, keratinization, stage of cervical cancer, and response to therapy based on $\mathrm{p}$ value $<0.25$. thus, a multivariate analysis was done revealing that stage and tumor size has a statistically significant relationship with survival of cervical cancer.

Table 2. Multivariate Analysis of the Relationship between Prognostic Factors and Survival

\begin{tabular}{lccccc}
\hline & B & p & HR & & L5\%CI \\
\cline { 5 - 6 } & & & & & \\
\hline Tumor size $<4 \mathrm{~cm}$ & & 0.122 & & 1.011 & 2.054 \\
Tumor size $4-8 \mathrm{~cm}$ & 0.366 & 0.043 & 1.441 & 0.768 & 2.555 \\
Tumor size $>8 \mathrm{~cm}$ & 0.337 & 0.272 & 1.400 & & \\
Cell diff Good & & 0.885 & & & \\
Cell diff Medium & -0.075 & 0.726 & 0.928 & 0.612 & 1.409 \\
Cell diff Bad & 0.041 & 0.900 & 1.042 & 0.551 & 1.970 \\
Cell diff Good + Medium & 0.164 & 0.580 & 1.178 & 0.659 & 2.107 \\
Cell diff Medium + Bad & -0.113 & 0.706 & 0.894 & 0.498 & 1.604 \\
Lymphovascular invasion & -0.096 & 0.675 & 0.908 & 0.580 & 1.423 \\
Keratinization & 0.235 & 0.220 & 1.265 & 0.869 & 1.841 \\
Stad IIB & & $<0.001$ & & & \\
Stad IIIA & 3.182 & $<0.001$ & 24.084 & 7.420 & 78.174 \\
Stad IIIB & 3.704 & $<0.001$ & 40.607 & 14.757 & 111.740 \\
Stad IVA & 5.113 & $<0.001$ & 166.128 & 55.508 & 497.202 \\
Therapy response Complete & & 0.419 & & & \\
Therapy response Partial & 0.154 & 0.307 & 1.167 & 0.868 & 1.568 \\
Therapy response Progressive & 0.379 & 0.313 & 1.461 & 0.700 & 3.051 \\
\hline \hline
\end{tabular}


The Kaplan-Meier's curve supports the result of the multivariate analysis. The curve shows that tumor size and stage of cervical cancer are associated with 5-year survival. Patients with 4-8 centimeters sized tumors were 1.441 times less likely to survive than tumors sized $<4$ centimeters. A confidence interval of $99.5 \%$ shows that there is a statistically significant association between cervical cancer stage and 5-year survival rate.

There is no significant difference in the correlation between active and passive smokers status (based on Briggman index) with 5-year survival rate analyzed using the Cox regression. This was shown every year during the follow-up period (first to fifth year).

\section{DISCUSSION}

In Indonesia, most cases of cervical cancer is found in its advanced stage, most commonly stage III. ${ }^{5}$ Based on INASGO Cancer Registry Reports, advanced stage cervical cancer (IIB-IVA) cases in Dr. Cipto Mangunkusumo Hospital has reached $71.2 \%$ of all cases of cervical cancer in $2013 .{ }^{6}$ Cervical cancer survival rate is mainly influenced by the size of the tumor and metastatic organ involvement. ${ }^{7}$ Overall, cervical cancer survival rate will worsen as cancer stage increases, regardless of other prognostic factors such as type of therapy or comorbidities. ${ }^{8-10}$

Five-year survival rate in cervical cancer based on stage is as follows: IA: $93 \%$, IB: $80 \%$, IIA: $63 \%$, IIB: $65.8 \%$, IIIA: $39.7 \%$, IIIB: $41.5 \%$, IVA: $22.0 \%$, and IVB: $9.3 \% .8-10$ This is consistent with our study $(\mathrm{p}<0.001)$. The method used in this study was a retrospective and prospective cohort. Patients were phoned to obtain smoking status and were followed up for 58 months using a prospective cohort method to calculate survival rate.

Aside from being a risk factor for cervical cancer, smoking also contributes to lower survival rate. ${ }^{11,12}$ The mechanism of the detrimental effects of smoking on the incidence of cervical cancer still remains unclear. However, it is believed, cigarettes suppresses the immune system against HPV infection making patients more prone to infection. ${ }^{13,14}$ In addition, smoking causes remodeling of cervical epithelium ${ }^{13}$ and disrupts tissue oxygenation which impacts the usage of radiation therapy. ${ }^{12}$ Waggoner et al, stated that the prognosis of cervical cancer patients who underwent chemoradiation therapy are poorer in smoking patients compared to non-smokers patients. ${ }^{12}$ However, in this study, smoking did not show significant differences on cervical cancer survival rate. Supporting our study, Fyles et al argues that there is no significant difference between smoking and levels of tissue oxygenation in patients with cervical cancer. ${ }^{15}$ Our study showed the proportion of cervical cancer patients who smoke is $8.2 \%$ compared to $91.8 \%$ who do not smoke. The low amount of patients who smokes could be a contribution to why our study shows that there is no significant relationship between smoking and cervical cancer survival rate.

The effect of being a passive smoker on the survival rate of cervical cancer is still debatable. A research in China by Cheng et al. concluded that

Table 3. Correlation Patient Smoking Status with 5-years Survival of Cervical Cancer

\begin{tabular}{|c|c|c|c|c|c|}
\hline & \multirow{2}{*}{ B } & \multirow{2}{*}{$\mathrm{p}$} & \multirow{2}{*}{ HR } & \multicolumn{2}{|c|}{$95 \% \mathrm{CI}$} \\
\hline & & & & Lower limit & Upper limit \\
\hline Brigmann Index 0 & & 0.828 & & & \\
\hline Brigmann Index 1 - 200 & 0.097 & 0.720 & 1.102 & 0.649 & 1.872 \\
\hline Brigmann Index 200-600 & -0.245 & 0.628 & 0.783 & 0.291 & 2.107 \\
\hline
\end{tabular}

Table 4. Correlation Patient Husband Smoking Status with 5-years Survival of Cervical Cancer

\begin{tabular}{lccccc}
\hline \hline & B & p & HR & \multicolumn{2}{c}{ 95\%CI } \\
\cline { 6 - 6 } & & & & Lower limit & Upper limit \\
\hline Brigmann Index 0 & & 0.382 & & & \\
BrigmannIndex 1-200 & 0.254 & 0.198 & 1.289 & 0.876 & 1.899 \\
BrigmannIndex 200-600 & 0.300 & 0.096 & 1.350 & 0.948 & 1.924 \\
BrigmannIndex $>600$ & 0.135 & 0.577 & 1.144 & 0.713 & 1.836 \\
\hline \hline
\end{tabular}


smoking women have a $73 \%$ increased risk for cervical cancer. ${ }^{16}$

Furthermore, this is clarified by Louis et al in their study which described that the risk only occur to women with active smoking habits. ${ }^{17}$ Their research concluded that passive smoking factor could not be the only deciding factor on whether one could have cervical cancer. $73.3 \%$ of subjects in our research are passive smokers. However, a flaw in our method was that the passive smoker patients were not asked the amount of exposure to cigarette smoke. Currently, the authors could not find any other researches investigating the correlation between passive smoking and cervical cancer survival rate and further research with a larger sample size is needed.

Various studies reveal that age is one of the prognostic factors for cervical cancer survival rate, but the significance of age as the sole determinant remains unknown. ${ }^{17-20}$ In this study, age shows no significant association $(\mathrm{p}=0.317)$ with the prognosis of advanced stage cervical cancer. This is consistent with Kumari et al,21 which showed that the age of patients has no significant correlation as a prognostic factor of cervical cancer. This could be due to most of our subjects $(82.2 \%)$ are between the ages 40-59 years old. According to literature, age only affects survival rate of cervical cancer in patients younger than 35 years old and older than 70 years old. ${ }^{20-23}$

Another factor investigated in our study is the association of multiparity with the incidence of cervical cancer. We found significant relationship between parity and cervical cancer survival rate ( $\mathrm{p}$-value $=0.599$ ). However, studies have shown that it is highly correlated. ${ }^{24,25}$ According to a multicenter study, by Muñoz et $\mathrm{a}^{25}$ and Liao et $\mathrm{al}^{26}$ the relationship between multiparity and cervical cancer survival rate is statistically significant $(\mathrm{n}=1673 ; \mathrm{p}$ $<0.0001$ ). The reason for discrepancy between our study and other studies could be contributed to the uneven distribution of subjects in our study. At our study, $64.1 \%$ of subjects have parity $\geq 3$ in a sample of only 270, while Muñoz et al conducted a multicenter study with 1673 subjects and equal distribution (53.1\% were multiparity). Another factor could be the cut-off point of multiparity in our study ( $>3$ births) are low compared to Muñoz et al, which is $>5$ births.

Coldman et al reported that women with a history of dysplasia, even with three consecutive nega- tive Pap tests, evidently still have an increased risk of cervical cancer compared with women with no history of dysplasia found with Pap smear screening. ${ }^{27}$ Mählcket alstated that the pap smear is the key in reducing the number of deaths from cervical cancer $(n=6799 ; p=0.003) .{ }^{28}$ In this study it was found that a history of pap smear does not provide a significant association with cervical cancer survival rate $(p=0504)$. This could be due to fewer numbers of subjects $(n=270)$, compared with studies of Mählck et al $(n=6799)$.

Studies have shown that tumor size of cervical cancer affects survival rate. Smaller tumors have a better prognosis compared to larger ones..$^{29,30}$ Various publications reveal that tumor size cervical cancer stage is a prognostic factor. ${ }^{21,30-33}$ This is in line with our results, which indicates size of mass correlates significantly to survival rate of cervical cancer (p-value $<0.001$ ).

Lymph node involvement is known to be poor prognostic factors for recurrence and survival rate in patients with cervical cancer. Lymph node involvement is also the basis for determining the schedule of adjuvant therapy in early-stage cervical cancer who received surgical therapy management. ${ }^{34-36}$

Locally advanced cervical cancer, which includes adenosquamous lymph node involvement post-operatively and involvement of pelvic lymph node, shown to be a poor prognostic factor as it lowers survival rate as well as increase incidence of recurrence. ${ }^{37}$ In this study, the presence of metastasis in the pelvic lymph nodes showed no significant relationship with cervical cancer survival rate. This can be explained by the differences in the proportion of cases with pelvic lymph node involvement and without the involvement of pelvic lymph nodes $(14.1 \%$ vs $85.9 \%$ ).

Squamous cell carcinoma is the most common type of cervical cancer. ${ }^{38-41}$ Prognostic significance of histologic types of cervical cancer cells is still debated. Adenocarcinoma has a worse prognostic value when compared to squamous cell carcinoma in predicting cervical cancer survival rate. ${ }^{38-41}$ In this study, the prevalence of squamous cell carcinoma is similar to various reports on the proportion of cases of cervical cancer by histology types. ${ }^{42,43}$ However, in this study, although the patients with squamous cell carcinoma have a lower survival rate, the relationship between the two is proven insignificant. 
Keratinization is a prognostic factor in determining the survival rate of squamous cell carcinoma. In our study, there is no significant association between keratinized squamous cell carcinoma with cervical cancer survival rate $(\mathrm{p}=0.236)$. This is in contrast to the study by Kumar et al, ${ }^{44}$ which revealed that keratinized squamous cell carcinoma provides a lower survival rate compared with non-keratinized squamous cell carcinoma. This difference could be explained by the number of subjects $(n=270)$ in our study compared to Kumar et al, as well as unbalanced ratio between subjects with keratinized and non-keratinized squamous cell carcinoma $(18.7 \%$ vs $81.3 \%$ ). Kumar et $\mathrm{al}^{44}$ reported total number of subjects was 68543 , showed a balanced ratio between the two groups of subjects ( $45.3 \%$ vs $54.7 \%$ ). According to Crissman et $\mathrm{al}^{45}$ and Reagan et al,46 tumor differentiation as a prognostic factor for survival rate of cervical cancer is still controversial. The data from our study showed no significant relationship found between cell differentiation to cervical cancer survival rate. $(\mathrm{p}=0.008)$.

\section{CONCLUSION}

The survival rate of advanced staged cervical in the first year to fifth was $86.3 \%, 43.3 \%, 24.4 \%, 23.3 \%$, $22.6 \%$ respectively and the average survival rate in our study was 22 months ( $\mathrm{SD}=4-58$ months). There is no statistically significant relationship between patients and patients' husbands smoking status to advanced stage cervical cancer survival rate. Furthermore, there is no association between the patient's severity of smoking to tumor size, stage of cervical cancer, response to therapy, cell differentiation and keratinization. A bivariate analysis was done and showed that tumor size, cell differentiation, lymphovascular invasion, response to therapy, keratinization and stage of the cervical cancer has a statistically significant effect on survival rate. However, the multivariate analysis done showed that only tumor size and stage of cervical cancer had a statistically significant impact on survival rate.

\section{REFERENCES}

1. Ferlay J, Shin H-R, Bray F, et al. Estimates of worldwide burden of cancer in 2008: GLOBOCAN 2008. Int J Cancer 2010 Dec 15; 127(12): 2893-917

2. Bosch FX, Qiao Y-L, Castellsagué X. The epidemiology of human papillomavirus infection and its association with cervical cancer. Int J Gynecol Obstet 2006; 94(Supp 1): $8-21$.
3. Domingo EJ, Noviani R, Noor MRM, et al. Epidemiology and prevention of cervical cancer in Indonesia, Malaysia, the Philippines, Thailand and Vietnam. Vaccine 26S 2008: 71-9.

4. Departemen Kesehatan Republik Indonesia. Profil Kesehatan Indonesia 2008. Jakarta: Departemen Kesehatan Republik Indonesia; 2009.

5. Aziz MF. Gynecological cancer in Indonesia. J Gynecol Oncol 2009; 20(1): 8-10.

6. Pardede T, Nizar R, Dewi C, et al. Kanker di Indonesia tahun 2010 data histopatologik. Jakarta: Badan Registrasi Kanker Perhimpunan Dokter Spesialis Patologi Indonesia; 2013.

7. Tewari KS, Monk BJ. Chapter 3 - Invasive Cervical Cancer. In: DiSaia PJ, Creasman WT, eds. Clinical Gynecologic Oncology. $8^{\text {th }}$ ed. Philadelphia: Mosby; 2012: 51119 .

8. Atalar B, Ozyar E. Principle of radiation therapy in gynaecologic oncology. In: Ayhan A, Gultekin M, Dulsun $\mathrm{P}$, eds. Textbook of gynaecological oncology. $2^{\text {nd }} \mathrm{ed}$. Ankara: Gunes Publishing; 2010: 401.

9. American Cancer Society. Survival rates for cervical cancer by stage. [Online]. (accessed August $23^{\text {rd }} 2014$ ). Available from: URL:http://www.cancer.org/cancer/cervicalcancer/detailedguide/cervical-cancer-survival.

10. National Cancer Institute. Surveillance, epidemiology, and end result program stat fact sheet: cervix uteri cancer.

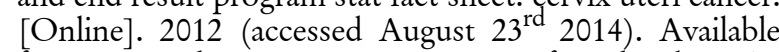
from: URL:http://seer.cancer.gov/statfacts/html/cervix. html.

11. Coker AL, DeSimone CP, Eggleston KS, et al. Smoking and survival among Kentucky women diagnosed with invasive cervical cancer: 1995-2005. Gynecol Oncol 2009; 112(2): 365-9.

12. Waggoner SE, Darcy KM, Fuhrman B, et al. Association between cigarette smoking and prognosis in locally advanced cervical carcinoma treated with chemoradiation: A Gynecologic Oncology Group study. Gynecol Oncol 2006; 103(3): 853-8.

13. Collins S, Rollason TP, Young LS, et al. Cigarette smoking is an independent risk factor for cervical intraepithelial neoplasia in young women: A longitudinal study. Eur J Cancer 2010; 46(2): 405-11.

14. Haverkos HW, Soon G, Steckley SL, et al. Cigarette smoking and cervical cancer: Part I: a meta-analysis. Biomed Pharma 2003; 57(2): 67-77.

15. Fyles A, Voduc D, Syed A, et al. The effect of smoking on tumour oxygenation and treatment outcome in cervical cancer. Clin Oncol 2002; 14(6): 442-6.

16. Zeng XT, Xiong PA, Wang F, et al. Passive smoking and cervical cancer risk: a meta-analysis based on 3,230 cases and 2,982 controls. Asian Pac J Cancer Prev 2012; 13(6): 2687-93.

17. Louie KS, Castellsague X, Sanjose Sd, et al. Smoking and passive smoking in cervical cancer risk: pooled analysis of couples from the IARC multicentric case-control studies. Cancer Epidemiol Biomarkers Prev 2011; 20(7): 1379-90.

18. Gupta MK, Revannasiddaiah S, Thakur P, et al. Prognostic factors ini carcinoma of the uterine cervix with concurrent-chemoraduotherapy. Global J Oncol 2013; 1: 5070. 
19. Monk BJ, Tian C, Rose PG, et al. Which clinical/ pathologic factors matter in the era of chemoradiation as treatment for locally advanced cervical carcinoma? Analysis of two Gynecologic Oncology Group (GOG) trials. Gynecol Oncol 2007; 105(2): 427-33.

20. Meanwell CA, Kelly KA, Wilson S, et al. Young age as a prognostic factor in cervical cancer: analysis of population based data from 10022 cases. BMJ 1988; 296: 386-91.

21. Kumari KG, Sudhakar G, Ramesh M, et al. Prognostic factors in cervical cancer: a hospital-based retrospective study from Visakhapatnam City, Andhra Pradesh. J Life Sci 2010; 2(2): 99-105.

22. Delaloye JF, Pampallona S, Coucke PA, et al. Younger age as a bad prognostic factor in patients with carcinoma of the cervix. Eur J Obstet Gynecol Reprod Biol 1996; 64: 201-5.

23. Dattoli MJ, Gretz HF $3^{\text {rd }}$, Beller U, et al. Analysis of multiple prognostic factors in patients with stage IB cervical cancer: Age as a major determinant. Int J Radiat Oncol Biol Phys 1989; 17: 41-7.

24. Castellsague X, Bosch FX, Munoz N. Environmental cofactors in HPV carcinogenesis. Virus Research 2002; 89(2): 191-9.

25. Munoz N, Franceschi S, Bosetti C, et al. Role of parity and human papillomavirus in cervical cancer: the IARC multicentric case-control study. Lancet 2002 Mar 30; 359(9312): 1093-101.

26. Liao SF, Lee WC, Chen HC, et al. Baseline human papillomavirus infection, high vaginal parity, and their interaction on cervical cancer risks after a follow-up of more than 10 years. Cancer Causes Control 2012; 23: 703-8.

27. Coldman A, Phillips N, Kan L, et al. Risk of invasive cervical cancer after three consecutive negative pap smears. J Med Screening 2003; 10(4): 196-200.

28. Ma?hlck CG, Jonsson H, Lanner P. Pap smear screening and changes in cervical cancer mortality in Sweden. Int J Gynecol Obstet 1994; 44: 267-72.

29. Canada Cancer Society. Prognosis and survival for cervical cancer. [Online]. 2014. Available at: URL: http:// www.cancer.ca/en/cancer-information/cancer-type/cervical/prognosis-and-survival/? region $=$ on.

30. Lindstro?m A. Prognostic factors for squamous cell cervical cancer. Umea? University Medical Dissertations, New Series No. 1350: 1-54.

31. Kim T-E, Park B-J, Kwack H-S, et al. Outcomes and prognostic factors of cervical cancer after concurrent chemoradiation. J Obstet Gynaecol Res 2012; 38(11): 1315-20.

32. Perez CA, Grigsby PW, Nene SM, et al. Effect of tumor size on the prognosis of carcinoma of the uterine cervix treated with irradiation alone. Cancer 1992. 1; 69(11): 2796-806.

33. Miller TR, Grigsby PW. Measurement of tumor volume by pet to evaluate prognosis in patients with advanced cervical cancer treated by radiation therapy. Int. J. Radiation Oncology Biol Phys 2012; 53(2): 353-9.
34. Song S, Kim J-Y, Kim Y-J, et al. The size of the metastatic lymph node is an independent prognostic factor for the patients with cervical cancer treated by definitive radiotherapy. Radiotherapy Oncol 2013; 108(1): 168-73.

35. Yeo RMC, Chia YN, Namuduri RPD, et al. Tailoring adjuvant radiotherapy for stage IB-IIA node negative cervical carcinoma after radical hysterectomy and pelvic lymph node dissection using the GOG score. Gynecol Oncol 2011; 123(2): 225-9.

36. Richard SD, Krivak TC, Castleberry A, et al. Survival for stage IB cervical cancer with positive lymph node involvement: a comparison of completed vs abandoned radical hysterectomy. Gynecol Oncol 2008; 109(1): 43-8.

37. Houvenaeghel G, Lelievre L, Rigouard A-L, et al. Residual pelvic lymph node involvement after concomitant chemoradiation for locally advanced cervical cancer. Gynecol Oncol 2006; 102(1): 74-9.

38. Mabuchi S, Okazawa M, Matsuo K, et al. Impact of histological subtype on survival of patients with surgicallytreated stage IA2-IIB cervical cancer: adenocarcinoma versus squamous cell carcinoma. Gynecol Oncol 2012; 127(1): 114-20.

39. Lee Y-Y, Choi CH, Kim T-J, et al. A comparison of pure adenocarcinoma and squamous cell carcinoma of the cervix after radical hysterectomy in stage IB-IIA. Gynecol Oncol 2011; 120(3): 439-43.

40. Galic V, Herzog TJ, Lewin SN, et al. Prognostic significance of adenocarcinoma histology in women with cervical cancer. Gynecol Oncol 2012; 125(2): 287-91.

41. Chen C-C, Wang L, Lin J-C, et al. The prognostic factors for locally advanced cervical cancer patients treated by intensity-modulated radiation therapy with concurrent chemotherapy. J Formosan Med Associat 2015; 114(3): 231-7.

42. Look KY, Brunetto VL, Clarke-Pearson DL, et al. An analysis of cell type in patients with surgically staged stage IB carcinoma of the cervix: a Gynecologic Onco-logy Group study. Gynecol Oncol 1996; 63(3): 304-11.

43. Lea JS, Coleman RL, Garner EO, et al. Adenosquamous histology predicts poor outcome in low-risk stage IB1 cervical adenocarcinoma. Gynecol Oncol 2003; 91(3): $558-62$.

44. Kumar S, Shah JP, Bryant CS, et al. Prognostic significance of keratinization in squamous cell cancer of uterine cervix: a population based study. Arch Gynecol Obstet 2009; 280 (1): 25-32.

45. Crissman JD, Budhraja M, Aron BS, et al. Histopathologic prognostic factors in stage II and III squamous cell carcinoma of the uterine cervix. Int J Gynecol Pathol 1987; 6: 97-103.

46. Reagan JW, Fu YS. Histologic types and prognosis of cancers of the uterine cervix. Int J Radiat Oncol Biol Phys 1979; 5(7): 1015-20. 